\title{
Effect of morphine on one-trial inhibitory avoidance in mice: Lack of state-dependency
}

\author{
CLAUDIO CASTELLANO \\ Istituto di Psicobiologia e Psicofarmacologia del CNR, Rome, Italy \\ and \\ JAMES L. McGAUGH \\ University of California, Irvine, California
}

\begin{abstract}
Intraperitoneal administration of morphine $(1.0$ or $2.5 \mathrm{mg} / \mathrm{kg}$ of body weight $)$ immediately posttraining in a one-trial inhibitory avoidance task significantly impaired the retention of DBA/2 mice tested $24 \mathrm{~h}$ after training. Administration of morphine ( 1.0 or $2.5 \mathrm{mg} / \mathrm{kg}$ ) prior to the retention test did not affect the retention performance of mice given posttraining injections of either saline or morphine (1.0 or $2.5 \mathrm{mg} / \mathrm{kg}$ ). These findings indicate that the amnestic effects of posttraining injections of morphine are not due to the induction of state-dependency. These findings are, therefore, consistent with the view that morphine impairs retention in mice by interfering with memory storage, rather than retrieval, processes.
\end{abstract}

A number of studies have reported that, in rats and mice, posttraining administration of the opiate receptor agonist morphine impairs memory in a variety of training tasks. For example, memory impairment following posttraining morphine administration has been observed in mice (DBA/2 strain) trained in a $Y$ water maze (Castellano, 1975), and in mice and rats trained in onetrial inhibitory avoidance and shuttle avoidance tasks (Castellano, Pavone, \& Puglisi-Allegra, 1984; Izquierdo, 1979; Jensen et al., 1978; Messing et al., 1981).

Recent studies have reported that the memory-impairing effect exerted by endogenous opioids, such as $\beta$-endorphin and the enkephalins, can be attenuated by the administration of the same hormones shortly prior to the retention test. These findings have suggested that the retention impairment exerted by these hormones may be a consequence of a drug-induced state-dependency (Izquierdo, 1984). That is, these studies suggest that good retention performance may require a congruence of the animals' hormonal state during testing with that induced following training. It is not yet clear whether such state-dependency is a consequence of treatments that produce retrograde amnesia in general, or whether the effects are limited to certain treatments. In a previous study, for example, we found no evidence of state-dependency in the memory-enhancing effects of the GABA antagonist picrotoxin (Castellano \& McGaugh, in press).

It is generally assumed that posttraining opiate treatments influence subsequent retention by modulating the

\footnotetext{
This research was supported in part by USPHS Grant MH 12526 and Office of Naval Research Contract NO0014-87-k-0518 (to J.L.McG.). Address correspondence to: Claudio Castellano, Istituto di Psicobiologia e Psicofarmacologia, via Reno 1 - 00198, Rome, Italy.
}

processes underlying the storage of information (McGaugh, 1973). If amnesia is produced by a treatment, it is obviously of theoretical (as well as practical) importance to determine whether the treatment impairs either memory storage or retrieval because of state-dependency.

The present research was undertaken to determine whether the retention-impairing effect exerted by morphine in mice is state-dependent. DBA/2 mice were trained in a one-trial inhibitory avoidance task, and the effects on retention of posttraining morphine administration were compared with those observed in mice treated with morphine both posttraining and prior to the retention test.

\section{METHOD}

\section{Subjects}

The subjects were 580 male DBA/2 mice (River Labs., Como, Italy). They weighed approximately $25 \mathrm{~g}$, were caged in groups of 8 with food and water available ad lib, and were maintained on a 12-h light-dark cycle (lights on at $0700 \mathrm{~h}$ ) in a constant temperature $\left(21^{\circ} \mathrm{C}\right)$ for 2 weeks prior to the experiments.

\section{Apparatus and Procedures}

The step-through inhibitory avoidance apparatus used, a $20 \times 20 \times 20 \mathrm{~cm}$ Lucite box with black walls and a grid floor, was similar to that previously described by Castellano et al. (1984). A long platform (12 cm long, $7.5 \mathrm{~cm}$ wide) extended from a small door $(4 \times 3 \mathrm{~cm})$ in the front of the box. The box was placed at the edge of a table with the platform extending out from the table. The inside of the box was dark. A 40-W lamp was positioned $50 \mathrm{~cm}$ above the platform.

On the training trial, the mice were placed, one at a time, on the platform facing away from the box. When the animal entered the box with all four feet, the step-through latency was recorded, the entry was closed with a sliding door, and a footshock $(0.7 \mathrm{~mA}$, 
Table 1

Effect of Posttraining Morphine on Retention Test Latencies

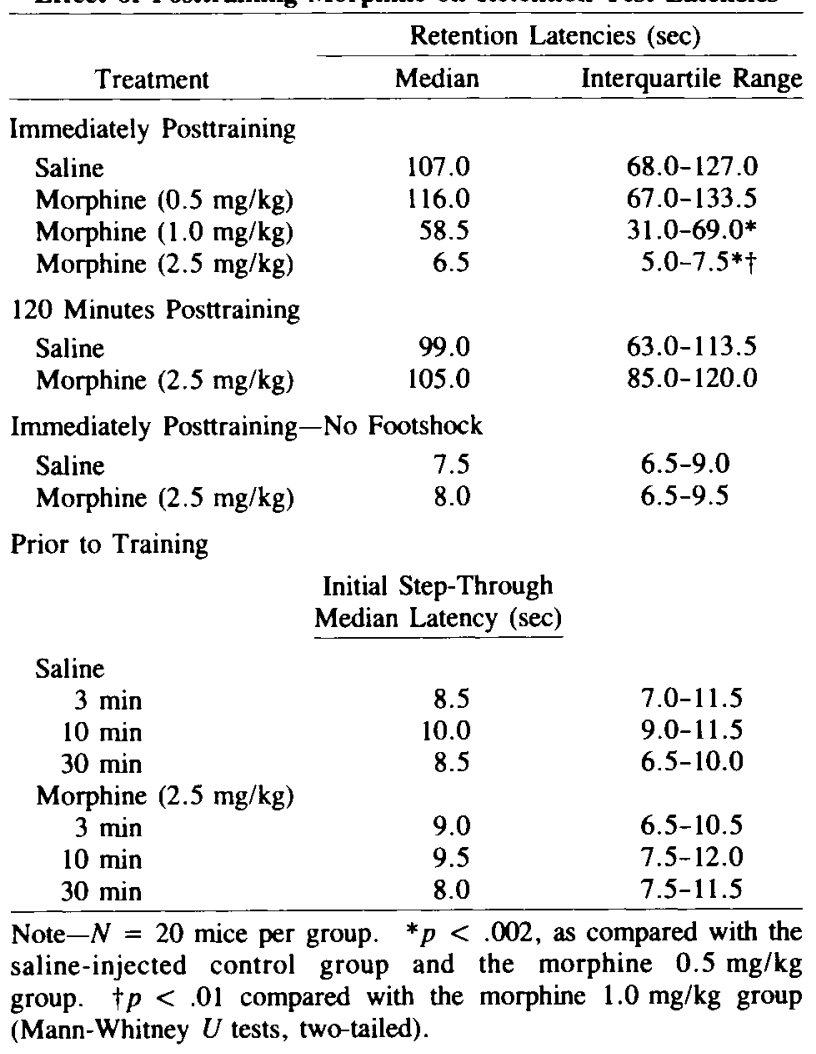

$1.0 \mathrm{sec}, 50 \mathrm{~Hz}$ ) was delivered. The mouse was then immediately returned to its home cage. On the retention test $24 \mathrm{~h}$ later, the mouse was placed on the platform as in the training session and the stepthrough latency (maximum of $240 \mathrm{sec}$ ) was recorded. Training and testing were performed between 1400 and $1700 \mathrm{~h}$. In all experiments, each group consisted of 20 mice.
In the first set of experiments (Table 1), three different groups of mice received i.p. injections of morphine $(0.5,1.0$, and $2.5 \mathrm{mg} / \mathrm{kg}$ of body weight, respectively) immediately after training. An additional group was injected with morphine $(2.5 \mathrm{mg} / \mathrm{kg}) 120 \mathrm{~min}$ after training to determine whether the drug's effect on subsequent retention varied with the training-treatment interval. To assess the possible aversive effects of morphine injections, another group did not receive footshock, but was injected with morphine $(2.5 \mathrm{mg} / \mathrm{kg})$ immediately after training and tested $24 \mathrm{~h}$ later. The performance of each of these groups was compared with that of a group of salineinjected mice. Finally, three other groups of mice were injected with morphine $(2.5 \mathrm{mg} / \mathrm{kg}) 30,10$, or $3 \mathrm{~min}$ prior to training in order to determine whether morphine affected response latencies at these postinjection intervals.

In a second set of experiments (Table 2), mice were injected posttraining with either saline or one of two doses of morphine (1.0 or $2.5 \mathrm{mg} / \mathrm{kg}$ ), and received an additional injection of saline or morphine at 30,10 , or $3 \mathrm{~min}$ prior to the retention test.

Morphine ( $\mathrm{HCl})$ (Carlo Erba, Milan, Italy) was dissolved in saline $(0.9 \% \mathrm{NaCl})$ and injected i.p. in the volume of $10.0 \mathrm{ml} / \mathrm{kg}$. The results were evaluated statistically by means of Mann-Whitney $U$ tests (two-tailed).

\section{RESULTS}

As shown in Table 1, posttraining administration of morphine $(1.0$ and $2.5 \mathrm{mg} / \mathrm{kg}$, but not $0.5 \mathrm{mg} / \mathrm{kg}$ ) induced dose-dependent impairing effects on retention. In addition, the retention latencies of mice injected with morphine $(2.5 \mathrm{mg} / \mathrm{kg}) 120 \mathrm{~min}$ after training did not differ from those of the saline control group. Furthermore, the step-through latencies of the mice that did not receive footshock, but were injected with saline or morphine $(2.5 \mathrm{mg} / \mathrm{kg})$ immediately after training did not differ significantly from each other. Moreover, there were no differences in the training step-through latencies of mice trained 3,10 , or $30 \mathrm{~min}$ after morphine injections $(2.5 \mathrm{mg} / \mathrm{kg})$.

Table 2

Effect of Morphine Administered Before Testing

on Retention Test Latencies of Mice Injected

with Saline or Morphine Immediately Posttraining

\begin{tabular}{|c|c|c|}
\hline \multicolumn{2}{|c|}{ Treatment } & \multirow{2}{*}{$\begin{array}{c}\begin{array}{c}\text { Retention } \\
\text { Latencies (sec) }\end{array} \\
\text { Median (IQ) } \\
\end{array}$} \\
\hline Posttraining & Prior to Retention Test & \\
\hline Saline & Saline* & $105.0(80.5-151.5)$ \\
\hline Saline & Saline $\dagger$ & $95.0(79.5-122.0)$ \\
\hline Saline & Salineł & $90.0(69.0-122.0)$ \\
\hline Saline & Morphine $(1.0 \mathrm{mg} / \mathrm{kg})$ & $88.0(59.3-135.0)$ \\
\hline Saline & Morphine $(2.5 \mathrm{mg} / \mathrm{kg})^{*}$ & $101.0(66.5-147.0)$ \\
\hline Saline & Morphine $(2.5 \mathrm{mg} / \mathrm{kg}) \dagger$ & $88.5(60.5-126.0)$ \\
\hline Saline & Morphine $(2.5 \mathrm{mg} / \mathrm{kg}) \ddagger$ & $96.5(64.5-122.5)$ \\
\hline Morphine $(1.0 \mathrm{mg} / \mathrm{kg})$ & Saline & $40.0(20.0-54.0) \S$ \\
\hline Morphine $(2.5 \mathrm{mg} / \mathrm{kg})$ & Saline & $8.5(7.5-11.0) \S$ \\
\hline Morphine $(1.0 \mathrm{mg} / \mathrm{kg})$ & Morphine $(1.0 \mathrm{mg} / \mathrm{kg})$ & $41.0(15.0-63.5) \S$ \\
\hline Morphine $(1.0 \mathrm{mg} / \mathrm{kg})$ & Morphine $(2.5 \mathrm{mg} / \mathrm{kg})$ & $53.5(28.0-75.0) \S$ \\
\hline Morphine ( $2.5 \mathrm{mg} / \mathrm{kg}$ ) & Morphine $(1.0 \mathrm{mg} / \mathrm{kg})$ & $7.0(6.0-9.0) \S$ \\
\hline Morphine $(2.5 \mathrm{mg} / \mathrm{kg})$ & Morphine $(2.5 \mathrm{mg} / \mathrm{kg})^{*}$ & $10.0(7.0-14.5) \S$ \\
\hline Morphine ( $2.5 \mathrm{mg} / \mathrm{kg}$ ) & Morphine $(2.5 \mathrm{mg} / \mathrm{kg}) \dagger$ & $10.0(7.5-11.5) \S$ \\
\hline Morphine $(2.5 \mathrm{mg} / \mathrm{kg})$ & Morphine $(2.5 \mathrm{mg} / \mathrm{kg}) \ddagger$ & $12.5(9.0-14.5) \S$ \\
\hline $\begin{array}{l}\text { Note-N=20 mice p } \\
\text { before testing. } ¥ \text { Trea } \\
\text { vs. the group that recei } \\
\text { (Mann-Whitney } U \text { tes }\end{array}$ & $\begin{array}{l}\text { *Treatment } 3 \text { min befo } \\
\text { nin before testing. } \$ p \\
\text { ostraining and the corres } \\
\text { led). }\end{array}$ & $\begin{array}{l}\dagger \text { Treatment } 10 \mathrm{~min} \\
\text { saline and } p<.002 \\
\text { rphine dose pretesting }\end{array}$ \\
\hline
\end{tabular}


Finally, as shown in Table 2, the administration of morphine $(1.0$ and $2.5 \mathrm{mg} / \mathrm{kg})$ prior to the retention test did not affect the retention latencies of the animals given posttraining injections of either saline or morphine (1.0 and $2.5 \mathrm{mg} / \mathrm{kg}$ ).

\section{DISCUSSION}

The findings of the first group of experiments are comparable to those of previous studies; that is, the administration of morphine immediately after training impaired retention in DBA/2 mice. This effect varied with the training-treatment interval; retention was not impaired in mice injected with the opiate $120 \mathrm{~min}$ after training. Furthermore, the effects of morphine on retention performance were not attributable to nonspecific influences on response latencies; that is, the opiate did not affect either training-response latencies when administered prior to training or retention latencies of unshocked controls when administered posttraining. These results confirm a number of previous findings obtained with mice and rats tested in a variety of experimental conditions (Castellano, 1975; Castellano et al., 1984; Izquierdo, 1979; Jensen et al., 1978; Messing et al., 1981).

It is clear from the findings of the second group of experiments that the administration of morphine prior to retention testing did not attenuate the memory-impairing effect of the posttraining administration of the drug. Thus, the findings of these experiments show that, at least in mice, the retention impairment produced by morphine is not a consequence of state-dependency based upon the congruence of states induced following training and at the time of retention testing. And, moreover, our findings do not support the view that retrograde amnesia produced by posttraining opiate treatments in general is due to the induction of state-dependency. Rather, our findings suggest that amnestic effects of opioids appear to depend upon the specific posttraining treatment used to impair memory.

Our findings are consistent with the view that morphine impairs retention by impairing the processes underlying memory storage. While it remains possible that the impaired retention is due to the effects of morphine on retrieval, rather than on storage, the fact that the effects are time-dependent is contrary to a retrieval interpretation. Certainly morphine did not generally impair retrieval in the present study; it was ineffective when injected $2 \mathrm{~h}$ following training. The virtue of the state-dependency hypothesis is that it suggests a means by which the retrieval process might be impaired by treatments administered shortly following training. However, our findings clearly indicate that the memory impairment produced by posttraining morphine administration is not based upon the induction of state-dependency.

These results are of interest when compared with the results of previous experiments examining the effect on memory of the three families of opioid peptides existing in the brain: $\beta$-endorphins, enkephalins, and dynorphins. Izquierdo (1984) reported that the memory-impairing ef- fects of $\beta$-endorphin and the enkephalins are reversed by treatment with the same substances prior to retention testing. In contrast, Introini-Collison, Cahill, Baratti, and McGaugh (1987) recently reported that, in mice, the memory-impairing effects of dynorphin are similar to those observed with morphine in the present research. The evidence suggests that both of these treatments impair retention by interfering with memory storage processes. Other recent findings have pointed to similarities between the effects exerted by morphine and the $x$-opioid receptor agonists tifluadom and bremazocine. For example, the memory impairments observed in DBA/2 mice tested in a one-trial inhibitory avoidance task, following the posttraining administration of all three of these drugs, are attenuated by prior familiarization of the animals with the apparatus (Castellano \& Pavone, 1986; Castellano et al., 1984; Pavone \& Castellano, 1985). The results of the present experiments, considered together with those obtained in previous studies of mice injected with dynorphin, suggest that the effects on memory of morphine and dynorphin, in this animal species, may involve physiological mechanisms different from those that are influenced by $\beta$-endorphin and by the enkephalins.

The findings of recent studies using inbred strains of C57BL/6 mice (C57) and DBA/2 mice (DBA) have suggested the existence of differences between the mechanisms of action of some endogenous and exogenous opioids in their effects on locomotor activity. The administration of $\beta$-endorphin decreased activity in the C57 strain (PuglisiAllegra, Castellano, Filibeck, Oliverio, \& Melchiorri, 1982), and the administration of enkephalins increased activity in the DBA strain (Puglisi-Allegra et al., 1986). Previous studies had shown that morphine treatment increased activity in the former strain and decreased it in the latter strain (Oliverio \& Castellano, 1974). Furthermore, in some brain areas (frontal cortex), enkephalin treatment has been shown to induce a decrease of dopamine turnover that was absent following morphine administration (Puglisi-Allegra et al., 1986).

Further studies are needed to clarify the nature of the differences between the mechanisms of action of $\beta$-endorphin, of the enkephalins, and of morphine in modulating memory storage processes.

\section{REFERENCES}

Castellano, C. (1975). Effects of morphine and heroin on discrimination learning and consolidation in mice. Psychopharmacologia, 42, 235-242.

Castellano, C., \& McGaugh, J. L. (in press). Retention enhancement with posttraining picrotoxin. Behavioral \& Neural Biology.

Castellano, C., \& Pavone, F. (1986). Effects of bremazocine on passive avoidance behaviour in mice. Archives Internationales de Pharmacodynamie et de Therapie, 283, 199-208.

Castellano, C., Pavone, F., \& Puglisi-Allegra, S. (1984). Morphine and memory in DBA/2 mice: Effects of stress and of prior experience. Behavioural Brain Research, 11, 3-10.

Introini-Coluson, I. B., Cahill, L., Baratti, C. M., a McGaugh, J. L. (1987). Dynorphin induces task-specific impairment of memory. Psychobiology, 15, 171-174.

IZQUIERDO, I. (1979). Effect of naloxone and morphine on various forms 
of memory in the rat: Possible role of endogenous opiate mechanisms in memory consolidation. Psychopharmacology, 66, 199-203.

IZQuIERDO, I. (1984). Endogenous state dependency: Memory depends on the relation between the neurohumoral and hormonal states present after training and at the time of testing. In G. Lynch, J. L. McGaugh, \& N. M. Weinberger (Eds.), Neurobiology of learning and memory (pp. 333-350). New York: Guilford Press.

Jensen, R. A., Martinez, J. L., Jr., Messing, R. B., Spiehler, V. R., Vasquez, B. J., Soumireu-Mourat, B., Liang, K. C., \& McGaugh, J. L. (1978). Morphine and naloxone alter memory in the rat. Neuroscience Abstracts, 4, 260.

McGaugh, J. L. (1973). Drug facilitation of learning and memory. Annual Review of Pharmacology, 13, 229-241.

Messing, R. B., Jensen, R. A., Vasquez, B. J., Martinez, J. L., JR., SPIEhler, V. R., \& McGaUGH, J. L. (1981). Opiate modulation of memory. In J. L. Martinez, Jr., R. A. Jensen, R. B. Messing, H. Rigter, \& J. L. McGaugh (Eds.), Endogenous peptides \& learning \& memory processes (pp. 431-443). New York: Academic Press. Oliverio, A., \& Castellano, C. (1974). Genotype-dependent sensi- tivity and tolerance to morphine and heroin: Dissociation between opiate-induced running and analgesia in the mouse. Psychopharmacologia, 39, 13-22.

Pavone, F., \& Castellano, C. (1985). Effects of tifluadom on passive avoidance behaviour in DBA/2 mice. Behavioural Brain Research, $15,177-181$.

Puglisi-Allegra, S. Castellano, C., Filibeck, U., Oliverio, A., \& MelchiorRi, P. (1982). Behavioural data on dermorphins in mice. European Journal of Pharmacology, 82, 223-227.

Puglisi-Allegra, S., Kempf, E., Cabib, S., Schleef, C., Gozzo, S., \& OLIVERIO, A. (1986). Opioid-induced hyperactivity and akinesia in the mouse: Involvement of dopaminergic systems. In G. Biggio, P. F. Spano, G. Toffano, \& G. L. Gessa (Eds.), Modulation of central \& peripheral transmitter functions (pp. 505-508). New York: Springer-Verlag.

(Manuscript received June 21, 1988; revision accepted for publication August 27,1988 .) 